\title{
Correspondence
}

\author{
Letters to the Editor should not exceed 500 words.
}

Ethics and Abortion. Sir Dugald Baird, F.R.C.o.G.; J. P. Crawford, M.D.; R. S.
Ferguson,

Implementing the Abortion Act. $\mathrm{H}$. A Robinson, M.B..............................173

Prescription Charges and Tuberculosis. W. D. Gray, M.B.; E. L. Feinmann, M.R.C.P. 174 Vocational Training for General Practice. B. Taylor, M.B. ..............................174

"Normal" Temperature. W. F. M. Wallace, M.D. ............... W. Wh

Price of Blood. A. J. Zuckerman, M.D.......174

Railwaymen and Drug Side-effects. J. S Grant, F.R.C.S.ED. ..........................175

Factor IX Levels and Oestrogens. Aileen $M$ Dickins, F.R.C.O.G............................175

Slimming and Sleep. J. T. Silverstone

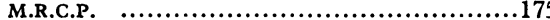

Brand Names. T. H. S. Burns, F.F.A.R.C.s...175
Long-term Corticosteroid Treatment of Asthma. I. Gregg, B.M.....................175

Deaths from Asthma. H. A. W. Forbes, D.M. 176 Pelvic Examination. J. A. McGarry, M.R.C.o.G. .................................176

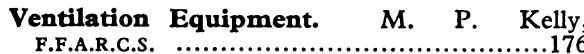
Measuring Blood-flow in Dialysis. R. $M$ Jameson, F.R.C.S.............................176 Oral Lichen Planus and Betamethasone. R. A. Cawson, M.B., F.D.S ......................176 Restrictions on Doctor in South Africa. L. H. Diamond, M.B......................177 Missing Loop. J. Breeze, M.R.c.o.g.; W. G Mills, F.R.C.o.G. ...............................177 High-dosage Fluphenazine. P. W. Richmond, M.R.C.P., D.P.M. ...........................178 Basilar Syndrome. J. H. Cyriax, M.D.........178 Screening Tests for Phenylketonuria. S. F Cahalane, M.B. ............................178
Lower Limb Injuries. N. Roberts, F.R.C.S....178 Human Heart Transplantation. E. J. Schulz, M.B.

Hypermobile Joints. P. H. Beighton, M.R.C.P.ED., and F. T. Horan, F.R.C.S....................179 Injury from Liquid Propane. H. J. Fenn, M.R.C.S. ...179

Volvulus of the Sigmoid Colon in Africa. S. P. Bohrer, M.D. .....................179 Panhypopituitarism after Cured Tuberculous Meningitis. J. A. M. Frederiks, M.D. 179

Overseas Service. D. C. Ingledew, B.M. .....179 Medical Charities Appeal. H. Dodd, F.R.C.S.180 Group Practice Payments. R. L. Luffing ham, D.I.H. ................................180

Health Centres. Margaret O. Thorpe, M.D....180 Prescription Charges. J. Cantlie, M.B. ......180 Doctors on the Box. W. Rhys-Jones, D.P.H....180

\section{Ethics and Abortion}

SIR,-I think it most unfortunate that your leading article, Ethics and Abortion (6 April, p. 3), should use such an extravagant and emotionally charged phrase as " sinister echo of something that ended 20 years ago at Nuremberg" in relation to the recent Abortion Act.

What the Act does is to make clear beyond doubt that termination of pregnancy is legal and that the decision to terminate or not should be left, as far as possible, to the clinical judgement of the doctors concerned, and that in reaching their decision doctors may take into account the effect of the patient's total environment on her health. This is a recognition that a wide variety of environmental factors can have a serious effect on the health of the mother and of the whole family. A mother's concern and anxiety about the welfare of her children is one of the most important of these factors. A National Opinion Poll in $1967^{1}$ showed that $65 \%$ of general practitioners favoured a new law at least as liberal as the present Act.

The persistent attempt to draw an artificial distinction between "social" and "medical" indications on the part of opponents of change is unrealistic. In my view change in ethical standards does not arise.-I am, etc., M.R.C. Medical Sociology
Research Unit,

DUgaLd BAIRD.

\section{REFERENCE}

1 New Statesman, 20 October 1967.

SIR,-As a practising psychiatrist at present who has to face the various dilemmas and new problems in this field so admirably discussed by Sir Roger Ormrod (6 April, p. 7) may I comment on your leading article ? (p. 3). Surely a decision by Parliament in a democracy cannot be described as sinister "superior orders" echoing Nuremberg 20 years ago (or rather what ended there and then). The boot could be argued to be on the other foot-namely, that doctors are prepared to dictate to the nation. I believe the real trouble in all this conflict is our profession's failure to accept psychological factors as respectable and real. Dr. Richard Hunter's personal view (p. 46) describes this state of affairs, but even some of Sir Roger Ormrod's supposed "non-therapeutic" situations would seem to many psychiatrists to have at least overtones in mental health.-I am, etc.,

$$
\text { Dartford, Kent. J. P. CRAWFORD. }
$$

* * It was a plea of "superior orders" in justification of a profession changing an ethical rule which we said would be the " sinister echo" not the superior orders themselves (in this case the provisions of the Abortion Act). -ED., B.M.F.

SIR,-The word ethics is apparently capable of a number of different interpretations. Your leader writer (6 April, p. 3) uses the arresting phrase, "Medical ethics are the collective conscience of the profession." A generalization of this order makes it obligatory for the profession (B.M.A. ?) to state its moral standpoint. To which school of moral philosophy does it adhere? Utilitarianism ? Hedonism ? Empiricism ? It cannot invoke some absolute authority behind its ethical rules, some theistic concept, for this would be arrogant usurpation of a religious function, and religion will have to be acknowledged to have precedence in rulegiving when it comes to matters of absolute authority.

The sinister echo of "superior orders" from Nuremberg over 20 years ago is admittedly far more chilling than the present echo from Tavistock House, but it is essentially the same echo. It will be interesting to learn, when the Representative Body takes its decisions, whether this "official" medical ethics will concede the right, sometimes even the duty, of the convinced dissenter to adopt the stand of conscientious objector. Or will the moral empire be essentially totalitarian in nature ?-I am, etc.,

\section{R. S. FERGUSON.}

Department of Sociology,
University of Salford,

Lancs.

\section{Implementing the Abortion Act}

SIR,-The Medical Defence Union (23 March, p. 759) is making the same mistake that the sponsors of the Abortion Act, 1967, have made in imagining that the ideal in theory will work the same way in practice. It is stated that practitioners interpreting the Act in good faith are unlikely to become involved in medico-legal complications. Later, however, it is stated the practitioner might have an action brought against him by a mother whose health had been injured by the continuance of pregnancy. Could this mean that if an inadequate mother has a nervous breakdown, be it immediately after or even months after, an unwanted child is born, the doctor might be faced with litigation ?

The weakness of this Act is its vagueness. It is its sponsors who suffer from the misconception that it is not abortion on social grounds. The greatest number of controversial cases will come under the heading of Section 1 (1) (a) (4 November 1967, p. 303), in which abortion may be carried out if " the continuance of pregnancy would involve risk ... of injury to the physical or mental health of the pregnant woman ... greater than if the pregnancy were terminated." Surely the word "grave" should have been inserted before " risk of injury." Every case of pregnancy carried to its natural conclusion surely carries more risk and strain on the mother than if it is terminated early on This vague condition, omitting as it does the word "grave," opens the floodgates to abortion by demand. To help the unfortunate woman with more children than she can cope with, the genuine case of physical illness, or psychiatric illness, the raped, the case of 
foetal abnormality, is praiseworthy. But who can delude himself that these will be the main problems ? The majority will consist of perfectly healthy women who are pregnant, in or out of wedlock, and who want to be rid of the baby. It is piously stated that "a doctor-patient relationship will be created and the doctor will then advise." What in fact will happen in these cases is that the woman will tell the doctor what she wants -an abortion, with the threat that if not she will go out of her mind and possibly kill herself. I have, indeed, already had a request on these lines from a woman who believed the Act was already in force. She did not get her request, but I was told that she knew of others in similar circumstances, but nearer London, whose doctors had been more obliging.

It must be admitted that without the word "grave" there is more strain and risk mentally and physically in bearing a child and caring for it, 'but I am sure the Act was not originated to relieve people of their responsibilities. If it was the idea that abortion is preferable to an unwanted child, then go ahead, abort, but do not be under any misconception that it is the doctor's decision. It is the woman's decision, and the doctor merely helps her carry it out. Abortion on demand ? Certainly, and without payment. -I am, etc.,

$$
\begin{aligned}
& \text { South Shields, } \\
& \text { County Durham. }
\end{aligned}
$$$$
\text { H. A. Robinson. }
$$

\section{Prescription Charges and Tuberculosis}

SIR,-I am extremely disturbed to note that pulmonary tuberculosis is not included in the list of conditions for which drugs will be prescribed without a prescription charge.

I understand that it is, however, included in the list of conditions where an appropriate charge for a period of three months or a year might be made. I consider, however, that any charge to a patient on chemotherapy for pulmonary tuberculosis will discourage many patients from taking chemotherapy, which is in all conscience difficult enough to administer to patients at home as it is. The end result of this, of course, will be relapse, further admission of patients to hospital, recurrence of positive sputum, and the spread of the disease with increasing cost to the National Health Service,

I make a strong plea, therefore, for every chest physician to write to his Member of Parliament to protest about this before it is too late.-I am, etc., North Chest Clinic,

$$
\begin{gathered}
\text { Aintree Hospital, } \\
\text { Liverpool } 9 .
\end{gathered}
$$

SIR,-There is one very important aspect of the discussion about prescription charges to which I would like to draw attention.

Whether tuberculosis is a chronic disease or not, everyone would agree that chemotherapy benefits not only the patient but the community. It should therefore be made as easy as possible. We must try to persuade the Minister of Health that treatment of this disease should be free of prescription charges. -I am, etc.,

Chest Clinic,

Queen Elizabeth Hospital,

L. Feinmann.

\section{Vocational Training for General Practice}

SIR,-The Royal Commission on Medical Education ${ }^{1}$ recommends that general practitioners and other doctors who will treat patients unsupervised should have six years' special training and experience after graduation leading to registration in their chosen specialty (see B.M.F., 13 April, p. 109).

I trust that the British Medical Association will endorse this recommendation. I cannot see general practice ever rising from the low state to which it has sunk until doctors do a compulsory course of vocational training. At the moment any doctor, after completing his year of preregistration posts, can step into a practice as an equal partner. In fact overworked principals are only too thankful for anyone they can get, because applicants for general practice are so scarce.

In no other branch of the profession can a medical man become fully established with so little training. If he wants to become a surgeon, a dermatologist, or a medical officer of health he has to submit to a rigorous course of training; but any Tom, Dick, or Harry can enter general practice, and if the practice happens to be in a densely populated area supported by a good hospital service he can get by with very little effort on his part.

It has been argued that a compulsory vocational course will increase the shortage of general practitioners. This may well be, but at least the profession will know that once compulsory vocational training is accepted those doctors who then apply to become a partner or principal in general practice will be of the right calibre, and the standard of general practice in this country will inevitably rise.-I am, etc.,

Bernard Taylor, Hon. Secretary and Treasurer
Tower Hamlets Division,
British Medical Association.

London E.3. REFERENCB

1 Royal Commission on Medical Education, Cmnd. 3569 , 1968. H.M.S.O., London.

\section{"Normal " Temperature}

SIR,-In view of the national change from degrees Fahrenheit to degrees Centigrade it seems likely that the clinical thermometer will receive a new scale. Would not this be a good opportunity to get rid, once and for all, of that little red line which suggests that temperatures above or below it are abnormal ?

There has long been good evidence that this arbitrary " normal" temperature is misleading. ${ }^{1}$ Ivy in 1944 reported on 276 American medical students whose temperatures were taken in class between 8 and 9 a.m. The mean temperature was $98.1^{\circ}$ F. $\left(36.7^{\circ}\right.$ C. $)$, and the range containing two standard deviations was $97.3-98.9^{\circ}$ F. $\left(36.3-37.2^{\circ}\right.$ C.). The total range for the 276 presumably normal students was $96.6-99.4^{\circ}$ F. (35.9$37.4^{\circ} \mathrm{C}$.)

I have analysed the temperatures of 50 Belfast medical students taken in class between 2 and 3 p.m. Results were slightly higher than those of Ivy, as might be expected at this time of day. The mean temperature was $98.4^{\circ}$ F. $\left(36.9^{\circ}\right.$ C. $)$, and the range containing two standard deviations was $97.6-99.2^{\circ}$ F. $\left(36.4-37.3^{\circ}\right.$ C. $)$. The absolute range was $97.5-99.4^{\circ}$ F. (36.4 $37.4^{\circ}$ C.).
DuBois, ${ }^{2}$ in a review of the literature on normal temperature, suggested a normal range of $35.8-37.4^{\circ} \mathrm{C}$. oral and 36.2$37.8^{\circ}$ C. rectal. For simplicity I would suggest a normal range of $36.0-37.5^{\circ} \mathrm{C}$. (96.8-99.5 $5^{\circ}$ F.), marked perhaps by green colouring, which would include most normal temperatures and exclude most abnormal temperatures, whether taken orally or rectally or in the axilla. Finally, a clinical thermometer which reads as low as about $30^{\circ}$ C. $\left(86^{\circ}\right.$ F.) might be useful to general practitioners in detecting accidental hypothermia.-I am, etc.,

William F. M. Wallace.

Department of Physiology,
Queen's University of Belfast.

REFERENCES

1 Ivy, A. C., Quart. Bull. Northw. Univ, med. School, 1944, 18, 22 Temperature, Hevinois, 1948 . Regulation of Body
uBois, E. F., Fer and the

\section{Price of Blood}

SIR,-A document by Cooper and Culyer, of the University of Exeter, setting out the arguments for the purchase of blood for transfusion, has recently been published (see also leading article, p. 129). The simple economic law of supply and demand cannot, of course, be denied (although the same argument can be extended to the supply of kidneys for transplantation). However, the authors of this lengthy paper have completely ignored the outstanding hazard of commercially supplied blood-namely, the risk of post-transfusion hepatitis. Thus while it is easy to dismiss emotional and altruistic motives for blood donation by healthy adults, it would be a mistake to accept that purchased blood would achieve the same criteria of probable low infectivity so far as the virus of hepatitis is concerned. Experience elsewhere indicates that the risk of posttransfusion hepatitis is very much greater when commercial sources are used, the reason being that complete reliance must be placed on the verbal history of past infections and current health of the donor. No satisfactory laboratory tests are available at present for the detection of asymptomatic and chronic carriers of the hepatitis virus. The integrity of the potential purveyor of blood must therefore be assumed. Payment for blood has been known to attract sometimes an undesirable section of the population, notably narcotic addicts (whose risk of serum hepatitis is notoriously high), chronic alcoholics, and others. Furthermore, experience has shown that when potential donors were turned down by some blood banks on health grounds they soon managed to sell their blood elsewhere. Consequently as long as the blood bank must rely upon accurate medical history and the truthfulness of the potential donor this risk must be taken into consideration.

The figures for post-transfusion hepatitis, both in the icteric and anicteric form, published from some centres in the United States, Germany, and Japan, are remarkably high. In a recent study the overall attack rate of post-transfusion hepatitis was found to be $14 \%$, but a very much higher incidence has also been reported." The overall mortality rate can be as high as $28 \% 0^{*}$ In 1963, in the United States, about 1.8 million patients were transfused, and it has been estimated that the incidence of clinical transfusion 